\title{
Zarządzanie ryzykiem demograficznym wobec procesu starzenia się zasobów pracy
}

Managing demographic risk towards the process of workforce aging

\section{Wprowadzenie}

Polska, podobnie jak większość innych krajów wysoko rozwiniętych, przechodzi radykalną zmianę porządku demograficznego. W strukturze wieku ludności dokonują się fundamentalne przeobrażenia: populacja, dotychczas relatywnie młoda, zaczęła się intensywnie starzeć (por. m.in. Rosset, 1959; Szukalski, 2011; Fihel, Okólski, 2018; Urbaniak i in., 2021). Proces ten powoduje szereg komplikacji w różnych obszarach życia społeczno-gospodarczego, m.in. w sferze zatrudnienia i pracy zawodowej.

Demografia rynku pracy to temat, który od długiego już czasu cieszy się sporym zainteresowaniem teoretyków ekonomii (por. m.in. Rosner, Stanny, 2008; Sipurzyńska-Rudnicka, 2018). Refleksji naukowej sprzyja fakt, że zmiany ludnościowe odciskają ogromne piętno na wielkości i kształcie zasobu siły roboczej. Problemy, z którymi borykano się w przeszłości, były jednak zasadniczo odmienne od dominujących obecnie. Dawniej, kiedy populacja rosła, a na rynek pracy wchodzili przedstawiciele kolejnych wyżów demograficznych, zasób siły roboczej był młody i łatwo dostępny. Głównym problemem był wówczas nadmierny przyrost populacji produkcyjnej w relacji do przyrostu liczby miejsc pracy. Powstawała w ten sposób nadwyżka, której gospodarka nie była w stanie należycie zaadaptować. Zjawisko to określone zostało mianem bezrobocia demograficznego (Wagner, 1984).

W tamtym czasie starsi pracownicy - uważani za fizycznie słabszych i gorzej wykwalifikowanych w porównaniu z osobami młodymi - byli traktowani jako 
"gorszy sort" zasobu siły roboczej i w związku z tym systemowo eliminowano ich z rynku pracy. W obliczu nadpodaży siły roboczej wczesna dezaktywizacja zawodowa nie była postrzegana jako przejaw niegospodarności. Mało tego, uważano ją za korzystną czy wręcz niezbędną do tego, aby „zwolnić” miejsca pracy i ułatwić rozpoczęcie kariery zawodowej ludziom młodym, którzy wchodząc na rynek pracy, zderzali się z barierą zatrudnieniową.

Ostatnimi czasy sytuacja pod tym względem jednak diametralnie się zmieniła. Po pierwsze, wskutek zawężenia dzietności na rynek pracy zaczęli wchodzić wąskim nurtem przedstawiciele niżu demograficznego, a wychodzić zeń zaczęli szerokim nurtem przedstawiciele roczników wyżowych, co w konsekwencji doprowadziło do zmniejszenia populacji produkcyjnej. Po drugie, radykalnym przeobrażeniom uległa również struktura wieku ludności produkcyjnej. W jej obrębie zaczęły narastać starsze generacje, a średni wiek pracowników zaczął się szybko podnosić (Jurek, 2012).

Dotychczasowy problem bezrobocia demograficznego został poniekąd samoczynnie rozwiązany, a w jego miejscu pojawił się nowy - nie mniej drażliwy z perspektywy ekonomicznej - problem niedoboru siły roboczej (Fihel, Okólski, 2018). Deficyt ten wymusił bardziej racjonalne podejście do gospodarowania zasobem ludzkim. Systematycznie zaczęto sięgać po rezerwy, które dotychczas nie były dostatecznie wykorzystywane na rynku pracy, w tym przede wszystkim po osoby w wieku okołoemerytalnym. Zarówno w teorii ekonomii, jak i w praktyce działalności biznesowej coraz większą uwagę zaczęto przykładać do potrzeb i problemów zawodowych tej grupy, a także do roli, jaką powinni oni odgrywać w gospodarce.

W Polsce aktywność zawodowa osób w wieku okołoemerytalnym kształtuje się na stosunkowo niskim poziomie w porównaniu z innymi krajami Unii Europejskiej (Kotowska, 2008; Kryńska, 2015; Błędowski, 2013). Jest to efekt oddziaływania różnych „sił”, które z jednej strony wypychają osoby starsze z rynku pracy, z drugiej zaś wciągają je w bierność zawodową (Urbaniak, 2007; Jurek, 2012). Efekt oddziaływania tych sił przejawia się nie tylko w „twardych” danych, opisujących stopę zatrudnienia czy wskaźnik aktywności zawodowej, ale również w „miękkich” danych, odnoszących się do sfery mentalnej. O ile ten pierwszy aspekt jest systematycznie monitorowany przez instytucje statystyki publicznej, to już ten drugi traktowany jest dużo bardziej pobieżnie, choć badania w tym zakresie dostarczają ciekawych informacji na temat postaw społecznych i dominujących wartości w odniesieniu do pracy zawodowej. Takie badanie przeprowadził m.in. IPSOS (2020). Wzięli w nim udział respondenci z 28 krajów. Jedno z poruszanych w nim zagadnień dotyczyło postrzegania granicy wieku, 
w której ludzie tracą fizyczną i psychiczną zdolność do pracy. Średnia z całego badania wyniosła 60 lat, jednak z dużymi różnicami pomiędzy poszczególnymi krajami. Najwyższą wartość zadeklarowali respondenci z czterech krajów: USA, Kanady, Chile i Szwecji. Stwierdzili oni, że człowiek traci zdolność do pracy w wieku 66 lat. Najniższą wartość zadeklarowali natomiast respondenci z Polski, którzy stwierdzili, iż ta zdolność zostaje utracona już w wieku 44 lat.

Na zainteresowanie omawianym tematem, poza przeobrażeniami demograficznymi, wpływ mają również reformy systemu emerytalnego. Chodzi dokładnie o zmiany w uprawnieniach emerytalnych: według aktualnych wytycznych przekroczenie ustawowego wieku emerytalnego ma stanowić przywilej, a nie, jak to wcześniej częstokroć bywało, przymus przejścia na emeryturę. W założeniu pracownicy sami mają decydować, kierując się indywidualnymi potrzebami i możliwościami, kiedy zakończyć aktywność zawodową. Zadaniem państwa ma być tworzenie zachęt (bodźców finansowych) i impulsów (bodźców pozafinansowych) do tego, aby moment opuszczenia rynku pracy został maksymalnie odłożony w czasie. Kluczowy wpływ na decyzje emerytalne mają jednak warunki pracy i możliwości stworzone przez pracodawców (Vickerstaff i in., 2004; Fisher, Chaffee, Sonnega, 2016). To firmy w dominującym stopniu kształtują skłonność i zdolność starszych pracowników do pozostania na rynku pracy i opóźnienia momentu zakończenia kariery zawodowej. Zwiększenie aktywności zawodowej wśród tej grupy nie jest zatem tylko zadaniem władzy publicznej, ale także (przede wszystkim) zadaniem przedsiębiorstw.

Przeobrażenia demograficzne zachodzące w całej populacji (skala makro) mają swoje oczywiste przełożenie na przeobrażenia demograficzne zachodzące w przedsiębiorstwach (skala mikro). Starzenie się zasobu siły roboczej w gospodarce narodowej to de facto starzenie się zasobu siły roboczej w podmiotach tworzących tę gospodarkę. Na poziomie przedsiębiorstwa proces ten przejawia się narastaniem udziału starszych pracowników² w obrębie całej kadry pracowniczej.

1 Ta zmiana związana jest $\mathrm{z}$ obniżeniem ustawowego wieku emerytalnego, ale także (przede wszystkim) z głębszą reformą zabezpieczenia emerytalnego (odejście od tzw. systemu o zdefiniowanym świadczeniu na rzecz tzw. systemu o zdefiniowanej składce), która zachęca, czy wręcz - jak to określił T. Szumlicz (2012, s. 5) - „wymusza” dłuższą aktywność zawodową.

2 „Starszy pracownik” to pojęcie nieostre i niejasne. Do określenia progu starości pracowniczej można zastosować różne kryteria: biologiczne, funkcjonalne, relatywne i metrykalne. Kryterium biologiczne odnosi się do poziomu sprawności psychofizycznej: pracownik staje się stary wtedy, gdy ze względu na zaawansowany wiek nie jest już w stanie wykonywać powierzonych mu zadań zawodowych albo wykonuje je mniej efektywnie niż osoby młodsze. Kryterium funkcjonalne odnosi się do perspektyw zawodowych: starszy pracownik to ten, który szczyt kariery ma już za sobą i przygotowuje się do wycofania z rynku pracy. Kryterium relatywne odnosi się do porównania jednostki z całą zbiorowością: za starszego pracownika uznaje się osobę, która jest istotnie 
Jest to istotne o tyle, że pod wieloma względami wykazują oni inne cechy aniżeli osoby młodsze. Mają swoje specyficzne potrzeby, problemy i preferencje. Ta odmienność jest efektem naturalnego procesu starzenia się człowieka (pracownika). Wraz z wiekiem zachodzą różnorakie zmiany natury biologicznej, psychologicznej i społecznej, które rzutują na postawę wobec pracy i jakość wykonywania zadań zawodowych. Zarządzający przedsiębiorstwami muszą to uwzględnić w swoich poczynaniach, bo w przeciwnym razie starsi pracownicy mogą stać się źródłem różnorakich problemów. Bez stosownych działań zapobiegawczych wzrost ich udziału może powodować szereg negatywnych konsekwencji. Pojawia się zatem nowe zagrożenie, które przyjęło się określać mianem „ryzyka demograficznego” (Strack i in., 2008, s. 119).

W polskim piśmiennictwie pojęcie ryzyka demograficznego jest stosunkowo nowe $e^{3}$. Jeśli dotychczas gdzieś się pojawiało, to bardziej w charakterze publicystycznym aniżeli naukowym. Niniejszy artykuł przybliża jego istotę. Jego celami są po pierwsze, rozpoznanie świadomości ryzyka demograficznego w przedsiębiorstwach zlokalizowanych na terenie Polski, a po drugie, zidentyfikowanie (potencjalnych) działań podejmowanych na rzecz zarządzania tym ryzykiem. Informacje zostały zebrane przy wykorzystaniu metody CAWI (Computer Assisted Web Interview). Badanie empiryczne miało charakter eksploracyjny i skierowane było na rozpoznanie poruszanych problemów, bez przyjmowania wstępnych założeń czy hipotez.

\section{Zarządzanie ryzykiem demograficznym w przedsiębiorstwie: ujęcie teoretyczne}

Ryzyko demograficzne związane jest $\mathrm{z}$ dwoma potencjalnymi zagrożeniami (Strack i in., 2008, s. 119). Po pierwsze, z możliwością wzmożonego (w krótkim

starsza niż średnia w danej populacji (w przedsiębiorstwie, branży itd.). Kryterium metrykalne odnosi się do liczby przeżytych lat: za starego pracownika uznaje się osobę, która przekroczyła jakąś ustaloną granicę wieku, najczęściej 50. lub 55. rok życia (Jurek, 2020).

3 Pojęcie ryzyka demograficznego stosowane jest powszechnie w finansach (ubezpieczenia) i polityce społecznej (zabezpieczenie społeczne) na określenie niekorzystnych z perspektywy systemu zmian demograficznych, mogących prowadzić do utraty stabilności finansowej tego systemu (np. nadmierne wydłużenie średniego trwania życia, wzrost obciążenia demograficznego itd.). Nie jest to jednak ten typ ryzyka, będącego przedmiotem zainteresowania niniejszego opracowania. Ryzyko omawiane w artykule dotyczy zagrożenia dla przedsiębiorstwa (takie jak np. utrata reputacji czy zmiana regulacji prawnych), którego źródłem są zmiany zachodzące w strukturze wieku kadry pracowniczej, a polegające na wzroście udziału (odsetka) starszych pracowników w ogólnej liczbie zatrudnionego personelu. 
czasie) przechodzenia na emeryturę pracowników, którzy ze względu na swoje unikatowe kwalifikacje (wiedzę, umiejętności) są trudni do zastąpienia, co może zakłócać ciągłość prowadzenia działalności biznesowej, a w skrajnym przypadku wręcz destabilizować funkcjonowanie firmy. Po drugie, z możliwością utraty produktywności w wyniku obniżenia wydajności pracy starszej części załogi. To obniżenie może być spowodowane m.in. dezaktualizacją kwalifikacji zawodowych, obniżeniem wydolności organizmu, spadkiem motywacji, a także wzrostem absencji chorobowej.

Omawiając istotę ryzyka demograficznego, należy zwrócić uwagę na szereg problematycznych kwestii, które dotyczą relacji między pracą zawodową a procesem starzenia się człowieka (pracownika). Wyniki badań są w tym zakresie dość niejednoznaczne. Rzeczą, która jest pewna i nie wzbudza większych kontrowersji, jest charakter zmian zachodzących w biologicznym cyklu życia. Skonstruowany jest on w ten sposób, że maksymalny pułap wydolności organizmu osiągany jest w okresie reprodukcyjnym. Po jego przekroczeniu, w miarę upływu czasu, zachodzi szereg regresywnych przeobrażeń powodujących obniżenie sprawności psychofizycznej, a także pogorszenie funkcji sensorycznych i zdolności adaptacyjnych organizmu. Te problemy zostały już szczegółowo zbadane i opisane w literaturze przedmiotu (por. m.in. Bortkiewicz, Makowiec-Dąbrowska, 2008). Ich wpływ na pracę zawodową pozostawia jednak wiele niejasności. Bezsprzecznie obniżona wydolność organizmu ogranicza zdolność wykonywania co niektórych zadań zawodowych, jednak zdecydowanie nie można tutaj mówić o prostym przełożeniu na zdolność do pracy czy wydajność pracy (por. m.in. Ilmarinen, 2001; Skirbekk, 2004; Slowey, Zubrzycki, 2018).

Po pierwsze, wraz z wiekiem zwiększa się zróżnicowanie między poszczególnymi jednostkami pod względem stanu zdrowia i poziomu sprawności. W rezultacie starsi pracownicy tworzą bardzo heterogeniczną zbiorowość. $\mathrm{O}$ ile więc uzasadnione jest twierdzenie, że mamy do czynienia z pewnymi generalnymi tendencjami zmian zachodzących wraz z postępem procesu starzenia się organizmu, to mówienie o jakimś ogólnym (średnim) spadku wydolności jest wielce mylące. Pracownik będący w sile wieku może być zarówno w dobrej kondycji i nie odstawać specjalnie od młodszej części załogi, jak i być obiektywnie niezdatny do realizacji takich samych zadań, jakie wykonują osoby młodsze.

Po drugie, zdolność do pracy związana jest bezpośrednio z charakterem pracy. Starsi pracownicy wykazują obiektywne trudności jedynie w wąskiej grupie zawodów wymagających maksymalnej sprawności sensorycznej, a także selektywnej uwagi, szybkiego przetwarzania nowych informacji, krótkiego czasu 
reakcji i długotrwałego utrzymywania wysiłku fizycznego. Niezdolność do pracy w tego typu zawodach nie oznacza jednak niezdolności do pracy w ogóle. Wraz z wiekiem można (czy wręcz należy) modyfikować obszar działań zawodowych, dostosowując go do bieżących możliwości i predyspozycji.

Po trzecie, proces starzenia się pracownika obejmuje szereg zmian biopsychospołecznych, które mają zróżnicowany wpływ na efektywność wykonywania zadań zawodowych. Część z tych zmian ma charakter negatywny i obniża wydajność pracy, inna część natomiast ma charakter pozytywny i może z powodzeniem tę obniżkę rekompensować (czasami nawet z nawiązką) (Börsch-Supan, Düzgün, Weiss, 2008). Jeśli chodzi o te pozytywne zmiany, to wraz z wiekiem wzrasta doświadczenie zawodowe: polepsza się znajomość procedur formalnych i nieformalnych, poszerza się zakres kontaktów interpersonalnych, wyrabia się intuicja zawodowa i utrwalają się automatyzmy działania. Ponadto wraz z wiekiem rozwijane są tzw. zdolności miękkie (psychospołeczne), związane z cierpliwością, umiejętnością pracy w grupie i wywieraniem wpływu społecznego.

Po czwarte, wydajność pracy jest wypadkową z jednej strony indywidualnych cech pracownika (sprawność, kwalifikacje, poziom motywacji), z drugiej zaś warunków materialnych i niematerialnych środowiska pracy (technologia, organizacja pracy, ergonomia). Obniżenie wydolności organizmu może być kompensowane poprzez modyfikacje warunków pracy, takie jak np. uelastycznienie czasu pracy, poprawa ergonomii czy wdrażanie technologii wspomagających (Gasińska, 2016). Tego typu usprawnienia są już wdrażane w wielu przedsiębiorstwach (por. m.in. EU-OSHA, 2017). Z doświadczeń tych firm wynika, iż programy wsparcia starszych pracowników pozwalają do pewnego stopnia ograniczyć spadek sprawności i tym samym niwelować negatywne konsekwencje starzenia się kadry pracowniczej.

Po piąte, wokół starszych pracowników narosło wiele mitów i stereotypów, które zwykle nie mają odzwierciedlenia w rzeczywistości. Głównie są one nacechowane negatywnie, ale zdarzają się również, aczkolwiek dużo rzadziej, te o charakterze pozytywnym (van Dalen i in., 2010). Do negatywnych stereotypów zaliczyć można opinie, jakoby starsi pracownicy szczególnie często przebywali na zwolnieniach lekarskich, a także byli niezdolni i/lub niechętni do nauki nowych rzeczy. Pozytywny wydźwięk ma natomiast pogląd, że takie osoby zachowują większą ostrożność i bezpieczeństwo w pracy niż osoby młodsze, rzadziej od nich angażują się w bezproduktywne zajęcia i wykazują mniejszą agresję w miejscu pracy. Ponadto wiele cech przypisywanych starszym pracownikom nie ma związku z zaawansowanym wiekiem, 
lecz z przynależnością do konkretnego pokolenia. Przykładowo, stosunkowo (w porównaniu z osobami młodszymi) gorsze posługiwanie się nowoczesnymi technologiami nie wynika $\mathrm{z}$ tego, że wraz $\mathrm{z}$ wiekiem narasta technofobia, lecz jest pokłosiem naturalnego braku styczności z tymi technologiami na wcześniejszych etapach życia.

Zarządzanie ryzykiem demograficznym wiąże się z jednej strony, z koniecznością oddziaływania na decyzje emerytalne starszych pracowników w taki sposób, aby ich dezaktywizacja zawodowa w możliwie najmniejszym stopniu destabilizowała funkcjonowanie firmy, $\mathrm{z}$ drugiej zaś, $\mathrm{z}$ takim kreowaniem środowiska pracy, aby było ono przyjazne starszym pracownikom, czyli korespondowało z ich specyficznymi potrzebami, możliwościami i preferencjami. W praktyce sprowadza się to do projektowania i wdrażania szeregu działań, które można podzielić na pięć kategorii (Strack i in., 2008):

1) „Ergonomia”: inicjatywy związane z dostosowaniem warunków i stylu pracy do potrzeb i możliwości starszych pracowników;

2) „Kultura organizacyjna”: działania związane z przeciwdziałaniem ageizmowi i kształtowaniem pozytywnych postaw wobec starszych pracowników;

3) „Zdrowie”: działania ukierunkowane na podtrzymanie kondycji psychofizycznej starszych pracowników i minimalizowanie utraty przez nich sił witalnych;

4) „Rozwój”: działania dotyczące szkoleń, awansów i motywowania pracowników będących u kresu swojej kariery zawodowej;

5) „Emerytura”: rozwiązania umożliwiające podtrzymanie aktywności zawodowej i „elastyczną" dezaktywizację kluczowych pracowników, w połączeniu z zapewnieniem sukcesji kompetencji i transferu wiedzy.

Koncepcja zarządzania ryzykiem demograficznym jest dość blisko powiązana z koncepcją zarząadzania wiekiem. Mimo wielu wspólnych elementów (celów i narzędzi), w pewnych obszarach zasadniczo różnią się one jednak od siebie. Ogólnie rzecz ujmując, zarządzanie wiekiem skupia się na potrzebach i możliwościach pracowników w różnym wieku. Choć potocznie jest ono kojarzone właśnie z działaniami prosenioralnymi w ramach polityki personalnej, w rzeczywistości zawiera znacznie szerszy katalog działań, w tym m.in. inicjatywy skierowane do młodych pracowników czy związane z tworzeniem tzw. zespołów multigeneracyjnych (Litwiński, Sztanderska, 2010). Zarządzanie ryzykiem demograficznym skupia się natomiast tylko na starszych pracownikach i poza kreowaniem przyjaznego dla nich środowiska pracy uwzględnia również działania związane z kształtowaniem ich postaw emerytalnych. 


\section{Opis procesu badawczego i charakterystyka próby}

Badanie zostało przeprowadzone w okresie od początku listopada do połowy grudnia 2019 r. Do zbierania informacji zastosowano metodę CAWI, tj. sondaż $\mathrm{w}$ formie ankiety internetowej. Respondentami byli menedżerowie i osoby odpowiedzialne za prowadzenie polityki kadrowej w przedsiębiorstwach zlokalizowanych na terytorium Polski. Operat losowania został wygenerowany $\mathrm{z}$ bazy EMIS (Emerging Markets Information Service). Zaproszenie do udziału w badaniu wysyłane było drogą elektroniczną, a kierowane było na adresy ogólne przedsiębiorstw i, jeśli było to możliwe, do komórek organizacyjnych odpowiedzialnych za prowadzenie polityki kadrowej. W piśmie przewodnim najpierw zaprezentowano ideę i cel badania, a następnie zwrócono się z prośbą o wypełnienie ankiety przez przedstawiciela firmy, którym może być albo menedżer wyższego szczebla, albo specjalista ds. HR.

Udział w badaniu był dobrowolny i anonimowy. Respondenci zainteresowani wynikami badania mogli zostawić swój adres e-mail, na który po jakimś czasie miał zostać przekazany bezpłatnie raport zawierający wyniki badania wraz z głównymi wnioskami i rekomendacjami. W założeniu raport ten miał stanowić zachętę do udziału w badaniu i formę gratyfikacji za poświęcony czas. Dodatkowo, aby zwiększyć motywację do wypełnienia ankiety, podkreślono unikatowość prowadzonego przedsięwzięcia naukowego, informując, że jest to pierwsze badanie poświęcone zarządzaniu ryzykiem demograficznym w Polsce.

Zaproszenie do wypełnienia ankiety wysłano do ok. 3000 firm. W tej grupie znalazły się wszystkie duże przedsiębiorstwa (zatrudniające przynajmniej 250 pracowników) oraz mniejsze, które zostały dobrane losowo. Na zaproszenie pozytywnie odpowiedziało 117 firm $(\mathrm{n}=117)$. Zwrotność wyniosła ok. 4\%. Niską wartość tego wskaźnika można tłumaczyć w trójnasób. Po pierwsze, baza adresów mailowych w systemie EMIS była częściowo nieaktualna i wiele wiadomości (ok. jedna czwarta) wracało, nie mogąc dotrzeć do adresata. Po drugie, e-maile wysyłane na adresy ogólne firm miały mocno ograniczone szanse „przebicia się” i trafienia do właściwych odbiorców. Po trzecie - można się domyślać, że był to efekt niskiej motywacji potencjalnych respondentów. Niechęć do udziału w badaniach internetowych jest dość dobrze znana ${ }^{4}$ i mogła mieć zasadniczy związek z niską efektywnością wysłanych zaproszeń.

4 Ta niechęć może być związana z powszechnym nadmiarem różnorakich badań w przestrzeni internetowej. Przypuszczalnie przesyt prowadzi do „zaimpregnowania” na prośby organizatorów badania i automatyczne ignorowanie zaproszeń do wypełnienia ankiety. Zdaniem R. Mącika (2014, 
Respondenci biorący udział w badaniu reprezentowali różne przedsiębiorstwa. Jeśli chodzi o poziom zatrudnienia, to najczęściej były to podmioty zatrudniające do 250 pracowników (29,06\%) oraz od 250 do 500 osób $(28,21 \%)$. Mniej więcej co czwarty zatrudniał od 501 do 1000 pracowników, a co siódmy powyżej 1000. W zdecydowanej większości (osiem na dziesięć) były to prywatne przedsiębiorstwa i najczęściej stanowiły własność polskiego kapitału. Najwięcej respondentów zajmowało się przetwórstwem przemysłowym (sześć na dziesięć). Co szóste przedsiębiorstwo określiło swoją branżę jako „pozostała działalność usługowa", a co dziesiąte działało w branży budowlanej.

\section{Sytuacja demograficzna badanych przedsiębiorstw}

Sytuacja demograficzna badanych przedsiębiorstw jest mocno zróżnicowana. Prawie połowa $(47,1 \%)$ respondentów stwierdziła, że struktura wieku zatrudnionego personelu jest dojrzała, tzn. najwięcej jest pracowników w średnim wieku (między 40. a 54. rokiem życia). W prawie co trzecim (29,9\%) kadra jest młoda, tzn. dominują pracownicy do 40. roku życia, a tylko w co dwudziestym trzecim $(4,3 \%)$ kadra jest stara, tzn. $z$ ilościową dominacją starszych pracowników (w wieku 55 lat i więcej). W pozostałych przypadkach (18,8\%) kadra jest mieszana, z mniej więcej równym udziałem wszystkich grup wieku.

Ostatnimi czasy liczba starszych pracowników nie zwiększyła się w większości $(59,8 \%)$ badanych przedsiębiorstw. Wzrosła tylko w co trzeciej $(33,3 \%)$ firmie, przy czym częściej $(24,8 \%)$ był on tylko nieznaczny, a rzadziej (8,5\%) wyraźny. Prawie co piętnasty $(6,8 \%)$ respondent nie był w stanie określić, czy liczba starszych pracowników w jego firmie zwiększyła się, czy też nie.

Jeśli chodzi o perspektywy na przyszłość, to nieco ponad jedna czwarta $(27,4 \%)$ respondentów nie spodziewa się wyraźnego zwiększenia liczby starszych pracowników. Niespełna jedna czwarta $(23,1 \%)$ jest przeciwnego zdania i uważa, że taki wzrost nastąpi. Aż dla połowy $(49,6 \%)$ respondentów jest to kwestia zbyt trudna do rozstrzygnięcia. Nie są oni w stanie udzielić jednoznacznej odpowiedzi na pytanie, czy liczba starszych pracowników wzrośnie, czy też nie. Ten brak rozeznania jest mocno zastanawiający, zwłaszcza że najczęściej cechuje on przedstawicieli bardzo dużych (zatrudniających od 501 do 1000 pra-

s. 127) jest to także spowodowane postrzeganiem tego typu badań jako „nudne, zabierające czas i potencjalnie intruzyjne". 
cowników) i największych (zatrudniających powyżej 1000 pracowników) przedsiębiorstw. W pierwszym przypadku udział osób wykazujących się niewiedzą w tym zakresie wyniósł aż $67 \%$, w drugim - 55\%. Dla porównania, w przypadku przedsiębiorstw zatrudniających do 250 pracowników wyniósł on „tylko" 35\%. Oczywiście można stwierdzić, że małe firmy mają tutaj uproszczone zadanie, w mniejszych zbiorowościach łatwiej bowiem o rozeznanie bieżącej sytuacji oraz o przewidywanie przyszłości. Niemniej jednak wydaje się, że większe podmioty, mimo obiektywnych trudności, powinny przywiązywać szczególną wagę do opracowywania tego typu prognoz. Bez tego trudno bowiem skutecznie koordynować politykę kadrową, a tym samym zapewnić zrównoważony rozwój firmy w długiej perspektywie.

Niezależnie od tych przyczyn można stwierdzić, że wzrost liczby starszych pracowników jest $\mathrm{w}$ polskich przedsiębiorstwach problemem nieuświadomionym. Na dobrą sprawę trudno się temu dziwić. Z perspektywy respondentów ocena bieżącej sytuacji demograficznej przedsiębiorstwa jest dobra i nie budzi większego niepokoju. Udział starszych pracowników był i wciąż jest niewielki (a przynajmniej akceptowalny). Nie wykazują przy tym obaw, aby miało się to niebawem radykalnie zmienić.

\section{4. Świadomość ryzyka demograficznego - wyniki badań}

Osobom biorącym udział w badaniu zadano pytanie o to, czy wzrost liczby starszych pracowników ma (jeśli już nastąpił) lub miałby (jeśli jeszcze nie odnotowano) wpływ na funkcjonowanie firmy, którą reprezentują? Pozytywną odpowiedź na to pytanie udzieliło $27,4 \%$ respondentów (zdecydowanie tak: $6,8 \%$ i raczej tak: 20,5\%), negatywną zaś 34,2\% (zdecydowanie nie: 3,4\% i raczej nie 30,8\%). Pozytywną odpowiedź częściej zaznaczały osoby, które wcześniej zadeklarowały wzrost liczby starszych pracowników w ich przedsiębiorstwie (33,3\%), aniżeli osoby, które takiego wzrostu nie deklarowały lub nie wiedziały, czy miał on miejsce $(24,4 \%)$. Wynika $\mathrm{z}$ tego, że tylko w co trzecim przypadku odnotowano, a w co czwartym planuje się odnotować związek przyczynowo-skutkowy między liczbą starszych pracowników a funkcjonowaniem firmy. Zdecydowana większość respondentów tej zależności jednak nie dostrzega. Oczywiście otwarte zostaje pytanie, czy faktycznie starzenie się personelu nie generuje żadnych konsekwencji dla badanych przedsiębiorstw, czy raczej respondenci nie zdają sobie z nich sprawy? Bazując na doświadczeniach innych krajów, gdzie proces demograficznego starzenia się jest 
dużo bardziej zaawansowany niż w Polsce, można stwierdzić, iż bliższe prawdy jest to drugie przepuszczenie. Ta rozbieżność między opiniami respondentów a stanem fatycznym potwierdza wcześniejsze domniemanie, że problem starzenia się pracowników jest $\mathrm{w}$ dużym stopniu nieuświadomiony.

Konsekwencje starzenia się kadry pracowniczej mogą być dla przedsiębiorstwa zarówno pozytywne (podnoszące efektywność prowadzonych działań biznesowych), jak i negatywne (obniżające ją). Osoby biorące udział w badaniu zapytano o to, czy w przypadku ich firmy ewentualny wzrost liczby starszych pracowników powoduje (lub powodowałby) więcej strat czy korzyści? Co trzeci $(33,3 \%)$ respondent wyraził opinię, że w ostatecznym rozrachunku bilans tych konsekwencji jest dodatni, czyli korzyści biorą górę nad stratami. Tych, którzy mieli przeciwne zdanie (więcej strat niż korzyści), było 15,4\%. Największa część respondentów (35,9\%) uznała, że ogólny bilans wychodzi na zero, czyli jest mniej więcej tyle samo strat, co korzyści, a 15,4\% respondentów nie miało zdania w tym zakresie.

Powyższy wynik można uznać za dość zaskakujący, oznacza bowiem, że starzenie się kadry pracowniczej znacznie (ponad dwukrotnie) częściej postrzegane jest w kategoriach szansy niż zagrożenia. Te wyniki są tak optymistyczne, że wręcz nasuwa się wątpliwość, czy oby na pewno są zgodne z faktycznymi przekonaniami. Czy respondenci, wbrew powszechnym stereotypom, rzeczywiście dostrzegają więcej zalet niż wad starszych pracowników, czy raczej starają się przestrzegać konwenansów i (świadomie lub podświadomie) powstrzymują się przed wypowiadaniem niepochlebnych opinii na temat osób starszych? Nie można wykluczyć również tego, że przedstawiane opinie są w pewnym stopniu wyrazem myślenia życzeniowego: respondenci mogli opisać, jak postrzegają rolę starszych pracowników (w tym również swoją, obecnie lub w przyszłości) w przedsiębiorstwie. Jest to ciekawe zagadnienie, którego rozstrzygnięcie wymagałoby podjęcia dodatkowych, pogłębionych badań.

Proces starzenia się zasobu siły roboczej w przedsiębiorstwie może generować różnego rodzaju problemy i komplikacje. Bazując na literaturze przedmiotu oraz wynikach dotychczas przeprowadzonych badań, wyszczególniono sześć zagrożeń, które potencjalnie mogą się pojawić w związku ze wzrostem liczby starszych pracowników: 1) wzrost absencji chorobowej; 2) dezaktualizacja kwalifikacji zawodowych; 3) spadek innowacyjności; 4) spadek wydajności pracy; 5) narastanie konfliktów między pracownikami w różnym wieku; 6) spadek motywacji do pracy. Dodatkowo wyszczególniono pięć kolejnych zagrożeń, które potencjalnie mogą się pojawić w związku z dezaktywizacją zawodową starszych pracowników: 7) wzmożone (w krótkim czasie) przechodzenie na emeryturę dużej 
liczby pracowników; 8) utrata kluczowych pracowników, którzy ze względu na swoje unikatowe kwalifikacje są trudni do zastąpienia; 9) ograniczona sukcesja kompetencji i wiedzy; 10) zakłócenie ciągłości prowadzenia działalności biznesowej; 11) wzrost kosztów funkcjonowania przedsiębiorstwa. Respondenci zostali poproszeni o oszacowanie poziomu (poważne/niewielkie/brak) każdego z tych zagrożeń w ich firmie. Uzyskane wyniki przedstawione zostały na rysunku 1.

Rysunek 1. Poziom nasilenia poszczególnych zagrożeń dla przedsiębiorstwa w związku z (ewentualnym) wzrostem liczby starszych pracowników oraz (ewentualnym) przechodzeniem ich na emeryturę

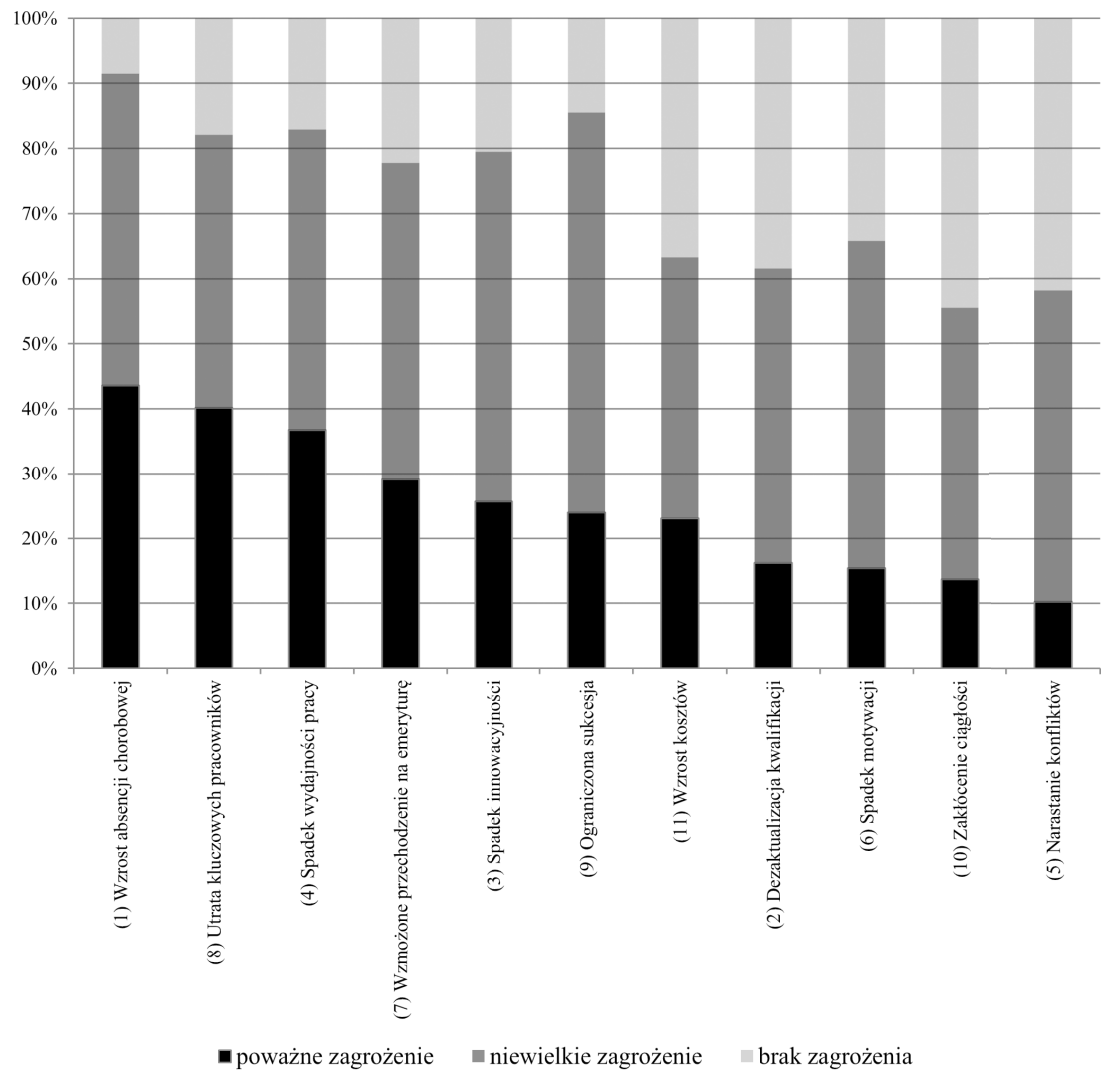

Źródło: opracowanie własne.

Najczęściej (43,5\%) jako poważne zagrożenie wskazywany był wzrost absencji chorobowej. Te deklaracje opierają się na powszechnym przekonaniu, że starsi pracownicy stosunkowo często chorują, zatem naturalną konsekwencją wzrostu ich liczby jest ogólne (w skali całego przedsiębiorstwa) zwiększenie wykorzystania urlopów chorobowych. Jak już zostało wcześniej zaznaczone, takie stereotypowe 
postrzeganie starszych pracowników jako szczególnie chorowitych jest oderwane od rzeczywistości i nie ma potwierdzenia w faktach.

Kolejnym zagrożeniem, które respondenci najczęściej (40,2\%) wskazywali jako poważne, jest utrata kluczowych pracowników, będących ze względu na posiadane kwalifikacje trudnymi do zastąpienia. To zagrożenie wiąże się z innym, które również dość często $(29,1 \%)$ było wskazywane jako poważne, a mianowicie wzmożone (w krótkim czasie) przechodzenie na emeryturę dużej liczby pracowników. $\mathrm{O}$ ile pierwszy z tych problemów dotyka jakości traconego zasobu, o tyle drugi dotyczy jego ilości. Okazuje się, że oba mają wysoką rangę zagrożenia.

W grupie czterech zagrożeń, które postrzegane są jako najbardziej poważne $(36,8 \%)$, znalazł się również spadek wydajności pracy. Jest to kompleksowe zagadnienie, obejmujące de facto kilka pomniejszych problemów składowych, takich jak np. obniżenie sprawności psychofizycznej, dezaktualizacja kwalifikacji zawodowych czy spadek motywacji.

\section{Zarządzanie ryzykiem demograficznym - wyniki badań}

Ogólnie rzecz ujmując, zarządzanie ryzykiem to podejmowanie decyzji oraz realizowanie działań, które zmierzają do osiągnięcia przez przedsiębiorstwo akceptowanego poziomu ryzyka (Jajuga, 2005). W praktyce proces ten sprowadza się do opracowania i wdrażania sekwencji różnych operacji ukierunkowanych na „opanowanie" ryzyka, czyli zapobieganie bądź ograniczanie jego negatywnych konsekwencji.

Zarządzanie ryzykiem demograficznym może być analizowane na dwóch płaszczyznach: deklaratywnej i proceduralnej. Pierwsza z nich obejmuje zbiór założeń i opinii składających się na postawę wobec ryzyka, ukierunkowującą ewentualne decyzje i działania. Jest to więc pewnego rodzaju potencjał, który może, ale nie musi mieć odzwierciedlenia w rzeczywistości. Płaszczyzna proceduralna zawiera natomiast zestaw realnych działań podejmowanych w związku z ryzykiem. Różnica między tymi dwoma obszarami sprowadza się do tego, że - kolokwialnie rzecz ujmując - pierwsza z nich ukazuje, co mogło i powinno być robione, a druga, co faktycznie jest robione.

Jeśli chodzi o płaszczyznę deklaratywną zarządzania ryzykiem demograficznym, to do jej rozpoznania wykorzystano cztery stwierdzenia (por. tabela 1), do których respondenci mieli się ustosunkować, przy czym udzielane przez nich 
odpowiedzi nie powinny przedstawiać ich osobistych opinii, lecz być zgodne z wartościami i sposobem działania firmy, którą reprezentują.

Tabela 1. Opinie respondentów dotyczące „filozofii” działania przedsiębiorstwa wobec ryzyka demograficznego ( $\mathrm{w} \%)$

\begin{tabular}{|l|c|c|c|c|c|}
\hline \multicolumn{1}{|c|}{ Stwierdzenie } & $\begin{array}{c}\text { Zdecy- } \\
\text { dowanie } \\
\text { zgodne }\end{array}$ & $\begin{array}{c}\text { Raczej } \\
\text { zgodne }\end{array}$ & $\begin{array}{c}\text { Ani zgod- } \\
\text { ne, ani } \\
\text { niezgodne }\end{array}$ & $\begin{array}{c}\text { Raczej } \\
\text { niezgodne }\end{array}$ & $\begin{array}{c}\text { Zdecy- } \\
\text { dowanie } \\
\text { niezgodne }\end{array}$ \\
\hline $\begin{array}{l}\text { Starzenie się kadry pracowniczej } \\
\text { stanowi jedno z kluczowych wy- } \\
\text { zwań dla polityki personalnej }\end{array}$ & 12,0 & 34,2 & 29,1 & 15,4 & 9,4 \\
\hline $\begin{array}{l}\text { Pracownicy, niezależnie od wieku, } \\
\text { stanowią strategiczny zasób } \\
\text { przedsiębiorstwa }\end{array}$ & 58,1 & 36,8 & 2,6 & 2,6 & 0,0 \\
\hline $\begin{array}{l}\text { Zdolność i chęć do pracy w star- } \\
\text { szym wieku w dużym stopniu } \\
\text { zależy od warunków pracy }\end{array}$ & 25,6 & 52,1 & 15,4 & 6,0 & 0,9 \\
\hline $\begin{array}{l}\text { Przedsiębiorstwo ma możliwość } \\
\text { aktywnego oddziaływania na } \\
\text { decyzje emerytalne pracowników }\end{array}$ & 15,4 & 35,0 & 26,5 & 17,9 & 5,1 \\
\hline
\end{tabular}

Źródło: opracowanie własne.

Z uzyskanych odpowiedzi wyjawia się obraz przedsiębiorstw, w których przynajmniej w sferze deklaratywnej - wysoko ceniony jest potencjał wszystkich pracowników (również tych starszych), a także dostrzega się (w dominującej większości) ważną rolę w kształtowaniu ich zdolności do pracy. Nieco słabiej wygląda sytuacja, jeśli chodzi o wpływanie na decyzje emerytalne starszych pracowników. Tylko połowa $(50,4 \%)$ respondentów dostrzega możliwość takiego działania w swojej firmie. Najrzadziej $(46,2 \%)$ respondenci zgadzali się ze stwierdzeniem, że starzenie się kadry pracowniczej jest kluczowym wyzwaniem dla polityki personalnej. Ten wynik można odczytać w dwojaki sposób. Po pierwsze, że ten problem zajmuje stosunkowo niską pozycję w hierarchii zagrożeń, z którymi borykają się badane przedsiębiorstwa. Taka interpretacja jest zgodna $z$ wynikami badań przeprowadzanych cyklicznie przez firmę Aon (2017, 2019). Z publikowanego przez nią „rankingu ryzyka” wynika, że ryzyko starzenia się pracowników, choć systematycznie zyskuje na znaczeniu, do niedawna jeszcze zajmowało bardzo odległą (przy samym końcu) pozycję. Drugie wytłumaczenie jest takie, iż starzenie się kadry pracowniczej nie jest postrzegane w kategorii wyzwania czy problemu. Taka interpretacja jest zgodna z wcześniejszymi wynikami badania i świadczy o spójności opinii wyrażanych przez respondentów. 
Jeśli chodzi o płaszczyznę proceduralną zarządzania ryzykiem demograficznym, to realne działania mogą przybierać różną postać. Biorąc pod uwagę ich zakres i charakter, można wyróżnić trzy style zarządzania: strategiczny, doraźny i bierny. Styl strategiczny polega na podejmowaniu systemowych działań, które ujęte są $\mathrm{w}$ strategii zarządzania zasobami ludzkimi. Styl doraźny to incydentalne działania, podejmowane ad hoc w reakcji na konkretną sytuację. Styl bierny natomiast to brak zorganizowanych działań.

$\mathrm{Z}$ uzyskanych odpowiedzi wynika, że w badanych przedsiębiorstwach ryzyko demograficzne najczęściej (50,4\%) zarządzane jest w sposób doraźny. Styl bierny występuje w czterech na dziesięć (38,5\%) przypadków, a tylko w co dziewiątym $(11,1 \%)$ ryzykiem zarządza się w sposób strategiczny. Generalnie w większych przedsiębiorstwach stosunkowo częściej występuje styl doraźny lub strategiczny, podczas gdy w tych mniejszych dużo częściej odnotowano styl bierny (por. rysunek 2).

Rysunek 2. Styl zarządzania ryzykiem demograficznym według wielkości przedsiębiorstwa mierzonej liczbą zatrudnionych pracowników (w \%)

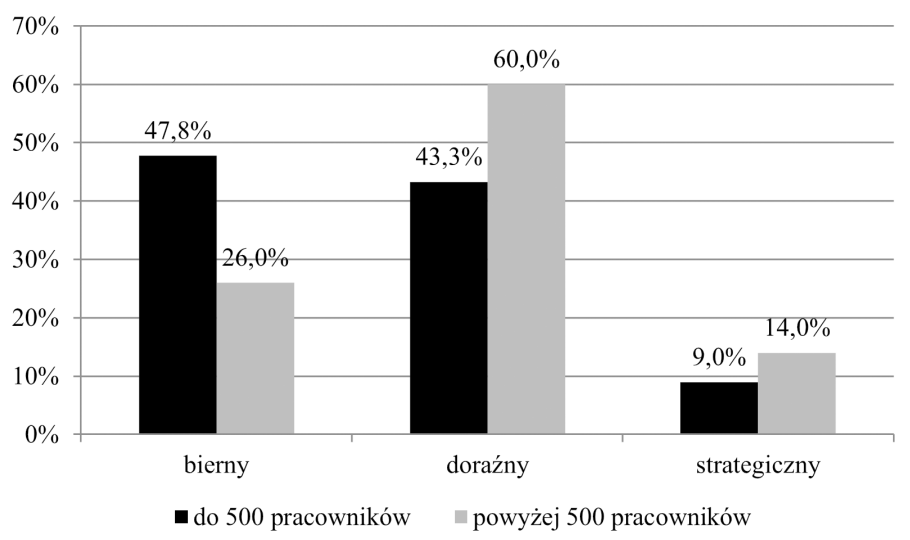

Źródło: opracowanie własne.

Ostatnia kwestia poddana badaniu również, podobnie jak poprzednia, dotyczyła płaszczyzny proceduralnej zarządzania ryzykiem demograficznym. Respondentom przedstawiono cztery obszary działań na rzecz starszych pracowników: 1) Poprawa ergonomii stanowiska pracy: dostosowanie warunków i stylu pracy do potrzeb i możliwości starszych pracowników;

2) Zmiana kultury organizacyjnej: inicjatywy związane z przeciwdziałaniem ageizmowi oraz kształtowaniem pozytywnych postaw wobec starszych pracowników; 
3) Profilaktyka zdrowotna: działania skierowane na podtrzymanie dobrej kondycji psychofizycznej starszych pracowników i minimalizowane utraty sił witalnych;

4) Kształtowanie decyzji emerytalnych: działania umożliwiające podtrzymanie aktywności zawodowej i „elastyczne” wycofywanie się z rynku pracy kluczowych pracowników.

Respondenci zostali poproszeni o ustosunkowanie się do każdego z tych obszarów poprzez udzielenie informacji, czy w reprezentowanych przez nich przedsiębiorstwach działania na tych polach: 1) są realizowane; 2) nie są realizowane, ale są planowane; 3) nie są realizowane i nie są planowane. Uzyskane wyniki zostały przedstawione na rysunku 3 .

Rysunek 3. Działania (realizowane, planowane, niepodejmowane) na rzecz starszych pracowników (w \%)

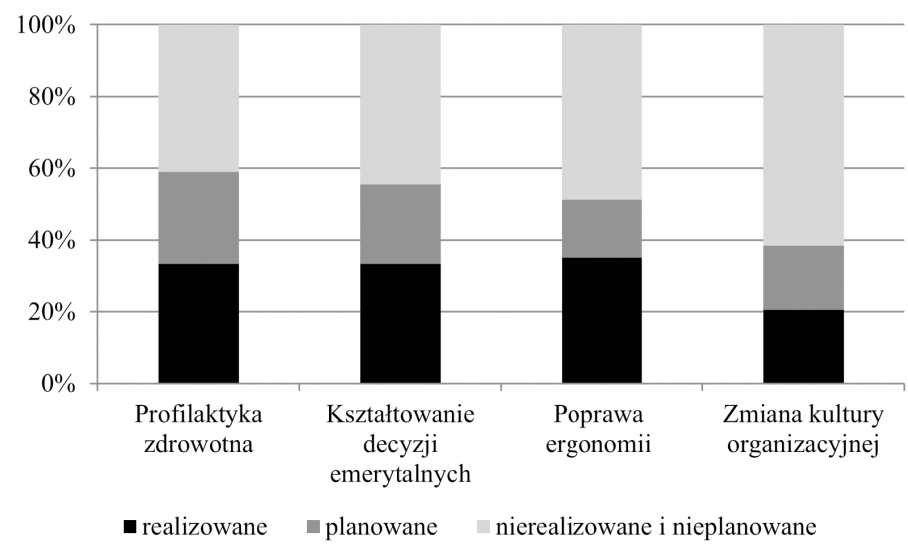

Źródło: opracowanie własne.

Co trzecie (35\%) przedsiębiorstwo prowadziło jakieś działania w zakresie poprawy ergonomii. Podobnie w zakresie profilaktyki zdrowotnej $(33,3 \%)$ i kształtowania decyzji emerytalnych (33\%). Co piąte (20,5\%) prowadziło działania w zakresie kultury organizacyjnej. Warto zaznaczyć, że przedsiębiorstwa, które podejmowały działanie $\mathrm{w}$ jednym $\mathrm{z}$ tych obszarów, $\mathrm{z}$ reguły angażowały się również (lub przynajmniej planowały się zaangażować) w nie na pozostałych polach. Świadczy to o kompleksowości realizowanych działań. Jeśli już w przedsiębiorstwie pojawiają się potrzeby czy możliwości podjęcia interwencji, to zwykle konieczne jest całościowe rozwiązanie problemu, we wszystkich jego aspektach.

Jak to zwykle bywa w przypadku tego typu wyników, można je interpretować dwojako: optymistycznie albo pesymistycznie. Tak jak szklanka może być do 
połowy pełna (co cieszy) lub do połowy pusta (co smuci), tak samo w (około) połowie badanych przedsiębiorstw podejmuje się lub planuje się podjąć działania na rzecz starszych pracowników, ale w pozostałych przypadkach takich działań się nie podejmuje, ani też nie planuje się podjąć. Ta indolencja u sporej części respondentów jest niepokojąca. Co prawda do pewnego stopnia jest ona usprawiedliwiona bieżącą sytuacją demograficzną, która została oceniana przez respondentów jako dość korzystna.

\section{Ograniczenia interpretacyjne wyników badania}

Przedstawione w artykule wyniki badania rzucają światło na wiele zagadnień i problemów związanych z ryzykiem demograficznym w przedsiębiorstwach. Mają one jednak dwa podstawowe ograniczenia interpretacyjne. Pierwsze z nich związane jest $\mathrm{z}$ metodą badania, a drugie $\mathrm{z}$ jego naturą.

Jeśli chodzi o pierwszą kwestię, to problemem jest bardzo niska zwrotność ankiet (ok. 4\%). Jest to ogólna trudność występująca podczas badań przeprowadzanych przez internet (Mącik, 2014). Rzutuje ona na jakość uzyskanych wyników i ogranicza możliwość ich generalizacji z próby na całą populację.

Poruszany problem jest ogólnie trudny do empirycznej eksploracji, a zwłaszcza przy wykorzystaniu sondażu diagnostycznego. Uzyskane wyniki nie odzwierciedlają bowiem stanu faktycznego, lecz subiektywne odczucia respondentów. Jest to generalny problem badań ankietowych. Osoby biorące w nich udział przedstawiają świat takim, jakim go widzą, a nie takim, jakim jest on w rzeczywistości. Mimo to uzyskane odpowiedzi wydają się mieć dość dużą wartość poznawczą. Umożliwiają m.in. poznanie „filozofii” radzenia sobie z wyzwaniem, jakim jest starzenie się kadry pracowniczej. Pozwoliły także uchwycić rozziew między sferą deklaratywną a proceduralną zarządzania ryzykiem demograficznym.

\section{Zakończenie}

Znaczenie ryzyka demograficznego ostatnimi czasy dynamicznie wzrasta. Potwierdzają to m.in. wyniki wspomnianych już wcześniej badań, które przeprowadzane są cyklicznie przez firmę Aon. O ile jeszcze w 2018 r. ryzyko starzenia się pracowników zajmowało w „rankingu ryzyka” odległą pozycję (40. w Polsce, 37. globalnie), o tyle już w 2020 r. wyraźnie wzrosła (16. w Polsce, 20. globalnie). Przyrost ten odnotowano we wszystkich branżach i regionach świata. Ponadto 
w najbliższych latach przewiduje się dalszy jej wzrost. W opinii autorów raportu (Aon, 2018) omawiane ryzyko niebawem zajmie trzynaste miejsce w globalnym rankingu, a w niektórych krajach wejdzie nawet do pierwszej dziesiątki (tzw. kluczowe ryzyka).

„Ranking ryzyka” stanowi ciekawą hierarchię problemów, z którymi borykają się przedsiębiorstwa, jednak nie ma on zbyt wiele wspólnego z rzeczywistym poziomem ich natężenia. Należy pamiętać, że jest to tylko plebiscyt odwzorowujący subiektywne opinie i przeczucia, a te w dużej mierze kształtują się pod wpływem pozamerytorycznych czynników, takich jak np. „medialność” określonych problemów. Mimo to ranking ukazuje aktualne trendy i priorytety, a to oznacza, że ryzyko demograficzne z roku na rok zyskuje na znaczeniu i niedługo stanie się jednym z priorytetowych wyzwań dla przedsiębiorstw na całym świecie, w tym również w Polsce.

Ryzyko jest immanentnie wkomponowane we wszelką działalność biznesową. Często jest ono kojarzone wyłącznie w kategoriach negatywnych, jako możliwość poniesienia straty. Jeśli chodzi o ryzyko demograficzne, to nie należy postrzegać go wyłącznie negatywnie, jako zagrożenie dla funkcjonowania przedsiębiorstwa, lecz także pozytywnie, jako szansę rozwojową. Metody i narzędzia wypracowane w ramach koncepcji zarządzania wiekiem tworzą szerokie spektrum możliwości skutecznego wykorzystania potencjału starszych pracowników i zwiększania produktywności całej załogi poprzez tworzenie zróżnicowanych pod względem wieku zespołów. Wdrażanie tego typu rozwiązań umożliwia osiąganie wieloaspektowych korzyści zarówno dla przedsiębiorstwa, jak i pracowników (sytuacja win-win). Korzyścią dla firmy może być m.in. zwiększenie dostępności zasobu siły roboczej, wzrost wydajności pracy, ograniczenie absencji chorobowej oraz poprawa wizerunku firmy jako pracodawcy. Pracownicy zaś mogą zyskać poprawę materialnych i niematerialnych warunków pracy, polepszenie stanu zdrowia, wzrost poczucia sprawczości i satysfakcji zawodowej.

Z przeprowadzonego badania płynie generalny wniosek, że wśród badanych przedsiębiorstw ryzyko demograficzne w dużym stopniu jest ryzykiem nieuświadomionym. Tylko niespełna jedna czwarta respondentów spodziewa się wyraźnego wzrostu liczby starszych pracowników. Pozostała część, czyli ponad trzy czwarte albo nie wie, czy taki wzrost nastąpi, albo jest wręcz przekonana, że do niego nie dojdzie. Respondenci nie mają też właściwego rozeznania na temat potencjalnych konsekwencji starzenia się kadry pracowniczej. W takich warunkach możliwość przeprowadzenia rzetelnej identyfikacji czy oceny ryzyka, a tym bardziej możliwość skutecznego sterowania tym ryzykiem, jest - rzecz jasna - bardzo mocno ograniczona. 
Brak świadomości ryzyka wydaje się większym zagrożeniem dla przedsiębiorstw niż samo ryzyko. Uniemożliwia bowiem właściwe przygotowanie się na potencjalne komplikacje, które mogą pojawić się w przyszłości. W dużym stopniu może to tłumaczyć aktualną indolencję: skoro problem jest niedostrzegalny, to jakiekolwiek interwencje z nim związane są traktowane jako zbędne. W związku z tym jako rekomendację dla kadry menedżerskiej należy wskazać przede wszystkim konieczność poszerzania wiedzy związanej z procesem starzenia się ludności oraz jego wpływem na funkcjonowanie przedsiębiorstw. Rzetelne rozeznanie sytuacji powinno stanowić punkt wyjścia do opracowania i wdrażania niezbędnych działań skierowanych na „opanowanie” ryzyka demograficznego, czyli zapobieganie bądź ograniczanie jego negatywnych konsekwencji.

\section{Bibliografia}

Aon. (2017). Zarzadzanie ryzykiem i ubezpieczeniami w firmach $w$ Polsce. Raport Aon Polska 2017/2018. Warszawa: Aon Polska.

Aon. (2019). Zarządzanie ryzykiem i ubezpieczeniami w firmach w Polsce. Raport Aon 2019/2020. Warszawa: Aon Polska.

Błędowski, P. (2013). Aktywność zawodowa osób w starszym wieku. W: M. Kiełkowska (red.), Rynek pracy wobec zmian demograficznych (s. 53-56). Warszawa: Instytut Obywatelski.

Bortkiewicz, A., Makowiec-Dąbrowska, T. (2008). Wiek a zdolność do pracy. W: J. Kleer (red.), Konsekwencje ekonomiczne i społeczne starzenia się społeczeństwa (s. 138167). Warszwa: Komitet Prognoz „Polska 2000 Plus” przy Prezydium Polskiej Akademii Nauk.

Börsch-Supan, A., Düzgün, I., Weiss, M. (2008). Labour productivity in an aging society. W: D. Broeders, S. Eijffinger, A. Houben (red.), Frontiers in Pension Finance (s. 83-96). Cheltenham: Edward Elgar.

van Dalen, H., Henkes, K., Schippers, J. (2010). Productivity of older workers: perceptions of employers and employees. Population and Development Review, 36(2), 309-330.

EU-OSHA. (2017). Healthy workplaces for all ages: Healthy workplaces good practice awards 2016-2017. Luksemburg: Publications Office of the European Union. Pobrano z https://healthy-workplaces.eu/sites/default/files/publications/documents/Healthy_Workplaces_Good_Practice_Awards_2016_2017_booklet.pdf (04.2020).

Fihel, A., Okólski, M. (2018). Przemiany cywilizacyjne, ludnościowe i starzenie się społeczeństwa. W: M. Okólski (red.), Wyzwania starzejącego się społeczeństwa. Polska dziś i jutro (s. 22-65). Warszawa: Wydawnictwa Uniwersytetu Warszawskiego.

Fisher, G., Chaffee, D., Sonnega, A. (2016). Retirement timing: A review and recommendations for future research. Work, Aging and Retirement, 2(2), 230-261. 
Gasińska, M. (2016). Ergonomia wobec osób w starszym wieku. Zeszyty Naukowe Uczelni Vistula, 46(1), 161-182.

Ilmarinen, J. (2001). Aging workers. Occupational and Environmental Medicine, 58(8), 546-552.

IPSOS. (2020). Global attitudes toward work and retirement. Pobrano z https://www. ipsos.com/sites/default/files/ct/publication/documents/2020-04/global_attitudes_toward_work_and_employment_-_rapport_complet.pdf (26.10.2020).

Jajuga, K. (red.). (2005). Teoretyczne podstawy zarządzania ryzykiem. Warszawa: PWN. Jurek, Ł. (2012). Ekonomia starzejącego się społeczeństwa. Warszawa: Difin.

Jurek, Ł. (2020). Starzenie się zasobu siły roboczej: studium demograficzno-ekonomiczne. W: A. Dolińska, R. Jończy (red.), Procesy migracyjne w południowo-zachodniej Polsce w kontekście sytuacji na rynku pracy. Wybrane zagadnienia (s. 124-162). Wrocław: Wydawnictwo Uniwersytetu Ekonomicznego we Wrocławiu.

Kotowska, I. (2008). Zmiany aktywności zawodowej a proces starzenia się ludności.

W: P. Szukalski, J.T. Kowalewski (red.), Pomyślne starzenie się w perspektywie nauk o pracy i polityce społecznej (s. 146-178). Łódź: Wydawnictwo Uniwersytetu Łódzkiego.

Kryńska, E. (2015). Srebrny rynek pracy, czyli o sposobach podtrzymywania i przywracania aktywności zawodowej starzejących się zasobów pracy. Polityka Społeczna, 42(7), 10-16.

Litwiński, J., Sztanderska, U. (2010). Wstępne standardy zarządzaniem wiekiem w przedsiębiorstwach. Warszawa: PARP. Pobrano z https://www.parp.gov.pl/ files/74/87/110/10073.pdf (04.2020).

Mącik, R. (2014). Ankiety internetowe w percepcji osób korzystających i niekorzystających z nich w pracy zawodowej. Studia Ekonomiczne, 195, 125-139.

Rosner, A., Stanny, M. (2008). Demograficzne aspekty zasobów pracy w Polsce do $2030 \mathrm{r}$. Polityka Społeczna, 35(1), 1-5.

Rosset, E. (1959). Proces starzenia się ludności. Studium demograficzne. Warszawa: Polskie Wydawnictwo Gospodarcze.

Sipurzyńska-Rudnicka, K. (2018). Przyszłość demograficzna Polski a rynek pracy. Wrocławskie Studia Politologiczne, 24, 104-118.

Skirbekk, V. (2004). Age and Individual Productivity. A Literature Survey. Vienna Yearbook of Population Research, 2, 133-153.

Slowey, M., Zubrzycki, T. (2018). Living longer, learning longer - Working longer? Implications for new workplace dynamics. Dublin: Dublin City University.

Strack, R., Baier, J., Fahlander, A. (2008). Managing demographic risk. Harvard Business Review, 86(2), 119-128. 
Szukalski, P. (2011). Starzenie się ludności-wyzwanie XXI wieku. W: P. Szukalski (red.), I. Oliwińska, E. Bojanowska, Z. Szweda-Lewandowska, To idzie starość - polityka społeczna a przygotowanie do starzenia się ludności Polski (s. 5-26). Warszawa: Instytut Spraw Publicznych.

Szumlicz, T. (2012). O (nie)podwyższaniu wieku emerytalnego w systemie zabezpieczenia emerytalnego. Polemika i głos w dyskusji. Wiadomości Ubezpieczeniowe, 2, 3-7.

Urbaniak, B. (2007). Trudności pracowników w wieku 45+ i ich problemy. Polityka Społeczna, 1, 10-14.

Vickerstaff, S., Baldock, J., Cox, J., Keen, L. (2004). Happy retirement? The impact of employers' policy and practice on the process of retirement. Bristol: Policy Press.

Wagner, A. (1984). Aspects of Demographic Unemployment. W: G. Steinmann (red.), Economic Consequences of Population Change in Industrialized Countries (s. 295302). Berlin: Springer-Verlag.

\section{Streszczenie}

Dokonujące się współcześnie radykalne przeobrażenia demograficzne mają zasadniczy wpływ na funkcjonowanie przedsiębiorstw. Wraz ze starzeniem się zasobu siły roboczej w gospodarce narodowej starzeje się także kadra pracownicza w podmiotach tworzących tę gospodarkę. Wzrost liczby starszych pracowników może stanowić źródło potencjalnych problemów, które zakłócają, a w skrajnych przypadkach wręcz destabilizują prowadzenie działalności biznesowej. Jest to nowe zagrożenie, które przyjęło się określać mianem ryzyka demograficznego. Celem artykułu jest po pierwsze, rozpoznanie świadomości ryzyka demograficznego w przedsiębiorstwach zlokalizowanych na terytorium Polski, a po drugie, zidentyfikowanie (potencjalnych) działań podejmowanych na rzecz zarządzania tym ryzykiem. Uzyskane wyniki badania własnego sugerują, że starzenie się zasobu siły roboczej w dużym stopniu jest ryzykiem nieuświadomionym. Tylko niewielka część respondentów spodziewa się wzrostu liczby starszych pracowników w ich firmie. Ponadto nie mają oni właściwego rozeznania na temat potencjalnych konsekwencji takiego wzrostu. W tych okolicznościach przeprowadzenie rzetelnej identyfikacji czy oceny ryzyka, a tym bardziej możliwość skutecznego sterowania nim, jest mocno ograniczone.

SŁoWA KLUCzowe: ryzyko demograficzne, starsi pracownicy, starzenie się ludności.

\section{Summary}

The radical demographic changes that are taking place nowadays have a fundamental impact on enterprises. Along with the aging of the labour force in the economy, the workforce in enterprises is also aging. Increase in the number of older workers may be a source of potential problems that may disrupt and, in extreme cases, even destabilise the functioning of businesses. This is a new threat that is called the demographic risk. 
The aim of the article is to recognise the awareness of demographic risk in enterprises located in Poland and also to identify the (potential) methods of managing this risk. The results obtained suggest that aging workforce is an unrealized risk. Only a minority of respondents expect an increase in the number of older workers in their company. Moreover, they do not have a proper recognition of the potential consequences of such an increase. In such circumstances, the ability to identify or assess the risk, and thus the ability to control the risk, is very limited.

KEYWORDS: demographic risk, older workers, population aging. 